Психология. Журнал Высшей школы экономики,

2021. T. 18. № 1. C. 145-166. DOI: 10.17323/1813-8918-2021-1-145-166

\title{
MATHEMATISCHE PSYCHOLOGIE: ИСТОРИЯ КОНФЛИКТА
}

\begin{abstract}
C.B. MOPO3OBA ${ }^{\mathrm{a}}$
${ }^{a}$ Санкт-Петербургский государственный университет; 199034, Россия, Санкт-Петербург, наб. Макарова, д. 6

Резюме

В исследовании рассматривается роль математической психологии (mathematische Psychologie) в немецком философском дискурсе XIX - начала XX в. История математической психологии рассматривается с позиций дисциплинарного подхода в историографии. Автор акцентирует внимание на реконструкции социальных механизмов определения и поддержания границ содержания дисциплины, их связи со структурой и особенностями функционирования университетов и научных учреждений, а также академических корпораций. Автор показывает, как математическая психология несколько раз оказывалась в центре дисциплинарных конфликтов. Сначала она была предметом полемики между гербартарианцами и неокантианцами. В середине века, после публикации «Элементов психофизики» Фехнера, физиологическое направление психологии представителями академической философии воспринималось как «математическая психология». К концу XIX в., уже после расцвета психофизики, во время подъема новой волны неокантианства гербартовские психология и психофизика стали предметом полемики Дильтея и Эббингауза о пересмотре методологических оснований психологии. Дискуссия начала ХХ в. об исключении экспериментальной психологии из состава философских дисциплин подводит итог обращению к математической психологии для определения дисциплинарных границ. История математической психологии показала, что даже в том случае, когда речь шла о математике как о методе, в философских дисциплинах разворачивались настоящие баталии, в которых представители разных методологических лагерей пытались отстоять свою независимость. Начавшись как философский спор, полемика постепенно приобрела иное значение. Негативное отношение к математической психологии стало восприниматься как признак всего методологически отсталого и потерявшего свою актуальность.
\end{abstract}

Ключевые слова: mathematische Psychologie, математическая психология, история психологии, дисциплинарный конфликт, академическая политика.

В немецких университетах XIX в. были заложены основы современной научной психологии. Именно в университетских стенах развернулись бои за определение места научной психологии и сохранение дисциплинарных границ философии. Традиционно этот процесс рассматривается исследователями истории психологии с точки зрения формирования экспериментальной психологии. Однако de facto он охватывает все философские дисциплины,

Исследование выполнено при финансовой поддержке РФФИ в рамках научного проекта № 19-013-00279. 
причем в связи с пересмотром их места в общей классификации наук. Вероятно, кризис немецкой науки начала XX в. и обсуждение предмета и места психологии в немецких университетах напрямую повлияли на специфику дальнейшего развития научной психологии.

Настоящее исследование было предпринято с целью анализа истории одной из ключевых психологических дисциплин XIX в. - «математической психологии». Мы попытались определить, какие факторы в XIX - начале XX в. оказали влияние на специфику отношения научного сообщества к применению количественных методов в психологических исследованиях. В процессе работы с немецкими источниками стало очевидно, что историю этого понятия невозможно рассматривать вне общего контекста дисциплинарной политики немецких университетов. Поэтому отдельный интерес для нас представляет дискурсивный аспект использования понятия «математическая психология» (mathematische Psychologie) немецкими психологами в указанный период.

Анализ существующей на данный момент историографии немецкой психологии и философии XIX - начала XX в. позволяет сделать вывод о том, что интерпретация происходивших событий сформировалась к 1970-м гг. и с тех пор значительных изменений не претерпела. История немецкой психологии и философии - это в первую очередь история «кризиса» психологии и философии. Авторы, изучавшие этот период, строили свое повествование, ведя читателя от политического контекста и специфики академических свобод немецких университетов к разрушению научных основ психологии и идеологическому триумфу «немецкого духа» (Поппер, 1992; Рингер, 2008; Kusch, 1995; Ash, 1980a). Современные авторы продолжают сложившуюся традицию (Mülberger, 2012) и/или пытаются переосмыслить историографию «кризиса». В последнем случае они абстрагируются от политического и идеологического контекста, что позволяет более гибко интерпретировать дискуссии о «кризиcе» (Sturm, 2012; Sturm, Mülberger, 2012; Юдин, 2015). Впрочем, встречаются и варианты политически нейтрального описания немецкой психологии и философии (Danziger, 1998; Hatfield, 2003). Чаще всего это англоязычные авторы, задача которых сводится к констатации факта: американская (английская, русская и т.д.) научная психология (new psychology) корнями уходит в немецкую экспериментальную психологию.

Мы видим свою задачу в описании процесса дисциплинарного становления психологии, свободного от поиска ростков нацистской науки в «науках о духе» XIX в. Во-первых, в связи с этим хронологические рамки исследования определяются XIX - началом XX в. Мы не рассматривали историю немецкой психологии веймарского периода. Во-вторых, комплекс интересующих нас источников был ограничен научными трудами и полемическими текстами ключевых философов указанного периода, писавших о методологии психологии. К материалам дискуссий о кризисе в немецкой психологии и философии мы обращались лишь в тех случаях, когда это непосредственно касается предмета нашего исследования.

С нашей точки зрения, историю математической психологии целесообразно описывать как историю научной дисциплины. Такой подход позволяет 
максимально полно осветить процесс становления научной психологии в Германии. В исследованиях, выполненных в парадигме дисциплинарного подхода, реконструируются социальные механизмы определения и поддержания границ содержания дисциплин, их связи со структурой и особенностями функционирования университетов и научных учреждений, академических корпораций (Backhouse, Fontaine, 2010; Дмитриев, Савельева, 2015).

\section{Научные дисциплины и немецкие университеты}

К моменту появления притязаний психологии на статус самостоятельной дисциплины в немецких университетах гумбольдтовская модель в течение уже многих десятилетий определяла характер поля философского знания и академическое оформление его границ. Немецкие университеты, согласно этой модели, были наделены внутренней независимостью, но при этом право назначать профессоров принадлежало государству. Кафедральная структура факультетов была внутренним делом университета, хотя профессорский штат определялся правительством.

Гумбольдтовская университетская модель повлияла на завершение процесса профессионализации исследовательской деятельности. Преподаватель обязан был быть исследователем. В поисках научной истины преподаватель и студент имели равный статус. Студенты свободно выбирали университеты, профессоров и академические курсы, которые хотели прослушать. Так реализовывался принцип «академической свободы». Особый статус выпускников университетов был закреплен на уровне системы государственных экзаменов и профессиональных привилегий. Студентами университета могли стать только выпускники гимназий (Андреев, 2009).

Так как немецкая университетская модель объединила научные исследования и обучение, процесс формирования новой науки неизбежно включал борьбу за дисциплинарные атрибуты: открытие лабораторий и кафедр, распределение профессорских ставок, право присуждения научных степеней и введение государственного экзамена по соответствующей специальности. В немецких университетах XIX в. выпускники после защиты диссертации могли претендовать на право чтения лекций и получение должности приват-доцента, а затем и профессора. Приват-доцентура не оплачивалась из средств казны и обеспечивалась только гонорарами слушателей лекций. Финансовая независимость имела и свои плюсы: приват-доценты могли самостоятельно выбирать темы научных исследований. В результате лаборатории немецких университетов стали мировыми научными центрами (Сокулер, 2001).

К середине XIX в. вся немецкая наука практически полностью была представлена университетскими преподавателями и студентами. Исследовательские группы обыкновенно состояли из учителя и нескольких учеников. К концу века стали появляться исследовательские институты экспериментальных наук, которые имели официальный штат научных сотрудников и лаборатории (Бен-Дэвид, 2014). Одним из таких исследовательских институтов стал Институт экспериментальной психологии В. Вундта. 
В результате гумбольдтовской реформы философские факультеты стали занимать центральное место в структуре немецких университетов. Они объединяли все теоретические науки, в том числе естественные (Шнедельбах, 2002). Философия получила особый статус в классификации наук. Тогда же была заложена идея о философском факультете как средстве воспитания немецкой нации (Демин, 2013).

Вследствие этого характерной чертой немецкой науки до 1830-х гг. включительно стало предпочтение спекулятивных методов эксперименту и количественному анализу. Лишь к середине века строгая модель науки, построенной по образцу физики, стала набирать популярность среди ученых. Д. Бен-Дэвид считает, что развитие естествознания в немецких университетах в первой половине века происходило вопреки реформе и господству философского метода в науке как ответная реакция на смену академических элит (Бен-Дэвид, 2014).

Психология традиционно воспринималась академическим сообществом как философская дисциплина. Более того, в немецкой философии второй половины XIX в. наблюдались тенденции пересмотра системы философских наук на базе психологии («психологизм» в философии) (Kusch, 1995). Это не удивительно, ведь психология, согласно учебным планам, уже к середине 1870-х гг. была одной из ведущих философских дисциплин и соперничала лишь с историей философии (Wundt, 1877).

Однако с 1880-х гг. стало появляться все больше философов, специализирующихся в области экспериментальной психологии, и возрастать количество психологических публикаций. Эта тенденция привела в начале XX в. к попыткам определить психологию как самостоятельную научную дисциплину. Ситуацию обострило стремительное развитие естественных наук в середине XIX в. Вследствие смены научных ориентиров спекулятивная философия начала терять ведущие позиции в системе немецких наук (Бен-Дэвид, Коллинз, 2002).

В целом к началу XX в. можно констатировать дисциплинарный конфликт внутри философских дисциплин. С одной стороны, происходил естественный процесс формирования экспериментальной психологии как новой научной дисциплины, что привело к ее притязаниям на академический статус. С другой стороны, этот процесс тормозился академическими и политическими реалиями. Более того, к началу XX в. сложилась такая ситуация, когда профессорскую должность на философском факультете можно было получить через приказ министерства вопреки желаниям администрации университета и коллег. Примером может служить назначение Э. Гуссерля экстраординарным профессором в Геттинген (Куренной, 2005).

\section{Математическая психология как дисциплина}

История «математической психологии» (mathematische Psychologie) берет начало в работах И. Канта. Он указывает на две основные проблемы применения математики в психологии: человеческая психика обладает только временны́ми, 
но не пространственными характеристиками, поэтому психические явления нельзя измерить; психику нельзя исследовать экспериментальным методом (Кант, 1994). По сути, вся дальнейшая история психологии, в особенности история немецкой психологической мысли XIX в., так или иначе связана с преодолением этих двух фундаментальных проблем.

После выхода в свет «Метафизических начал естествознания» события развивались закономерным образом. Каждый новый ниспровергатель кантовского скептицизма считал себя обязанным заявить об «историческом значении» трудов своего предшественника. Первым автором, труды которого уже в середине XIX в. стали иметь историческое значение, стал основатель математической психологии И.Ф. Гербарт.

Важно отметить, что свое повествование в программных сочинениях Гербарт строил по полемическому принципу. Сначала он возражает на тезисы Канта о невозможности применения математики в психологии и измерения психических явлений и лишь после этого приступает к изложению собственной позиции (Гербарт, 2007a). Полемизируя с Кантом, он заявлял, что нет препятствий к построению математической модели психики еще до измерений: «Можно вычислять изменяемость известных величин и их самих, поскольку они изменяемы, не определяя их вполне; на этом основывается весь анализ бесконечного. Далее, можно гипотетически принять законы изменения величин и, вычислив следствия, вытекающие из этих гипотез, сравнивать их с опытом» (Гербарт, 2007б, с. 64). Гербарт видел свою задачу прежде всего в формулировке метода применения математики в психологии. По образцу естественных наук он считал необходимым описать каузальные связи психических явлений, рассуждал о статике и механике духа, пытался выявить суммы простых душевных сущностей, далее неделимых, которые могут быть подвергнуты математическому анализу. Решение проблемы психического времени и пространства Гербарт видел в создании учения о механике духа. Не проводя полной аналогии между движением физических тел в пространстве и психических явлений в душе, он тем не менее говорил о представлениях, которые могут «погружаться» и «подниматься», достигая «механического порога» сознания, т.е. использовал пространственную риторику для описания интенсивности представлений. С его точки зрения, наши представления, чувства и аффекты в каждую единицу времени бывают больше или меньше, сильнее или слабее. Следовательно, можно говорить о количественных характеристиках психических явлений: о напряженности каждого единичного представления, степени задержки между какими-нибудь двумя представлениями, степени связи между несколькими представлениями (ассоциации идей) и др. Но, как известно, эмпирических исследований Гербарт не проводил.

Дальнейшее развитие математическая психология получила в трудах М.-В. Дробиша. В предисловии к работе 1850 г. он писал, что математическая часть гербартовской психологии не угодила ни психологам, ни математикам. Его психология - только абстрактная подготовка к будущей математической психологии. Но работа Гербарта «является памятником завидной прозорливости и редкой настойчивости» (Drobisch, 1850, S. vi). Дробиш оспаривал 
тезис о невозможности измерить психические явления, предлагая видеть в проблеме теоретическую и практическую измеримость. Вопрос о том, как можно решить проблему несоизмеримости психических явлений на практике, остается открытым. Но, добавлял он, возможно, определенные результаты в этом направлении можно было бы ожидать со стороны физиологии. В целом аргументация Дробиша постоянно отсылает к опыту физических наук.

В 1851 г. Г. Фехнер заявил, что в основе математической психологии должны лежать измерения не психических, а физиологических явлений, что подход Гербарта неубедителен. Фехнер сформулировал основные принципы психофизики, дав свой ответ на тезисы Канта. Он предложил косвенное измерение психических параметров через физические, которые, в отличие от психических, обладают всеми необходимыми характеристиками для применения к ним метрических шкал. Фехнер исходил из того, что любой психический акт есть совокупность возбуждений, а возбуждение, по его мнению, пропорционально логарифму от силы любого внешнего события (Fechner, 1987).

В 1860 г. Фехнер опубликовал »Элементы психофизики». По традиции, в предисловии к первому тому дается определение исторического значения трудов Гербарта: «Заслуга Гербарта всегда останется не только в том, что он впервые высказал возможность математического взгляда на [психологические] связи, но прежде всего в том, что он первый осуществил остроумную попытку разработать такой взгляд; и все, кто после него, будут лишь последователями» (Fechner, 1860, S. х).

Наиболее важной частью концепции Фехнера являются разработанные им психофизические методы измерения, которые позволили экспериментально проверить закон Вебера. Суть этого закона сводится к тому, что существует пропорциональная зависимость между логарифмом силы физического раздражителя и силой ощущения. В современной психофизиологии хорошо известно, что в случаях, когда производятся косвенные измерения психических характеристик через физические величины, например, время реакции или КГР (см.: Суходоев, б.г.), мы получаем переменную, значения которой имеют логнормальное распределение. Процедура логарифмирования приводит к тому, что распределение значений такой переменной становится близким к нормальному.

Фехнер предложил методы для измерения ощущений, точнее, он систематизировал методы, которые были разработаны Вебером и др. Измерять ощущения он предлагал в интервальной шкале. Согласно закону Вебера-Фехнера, приращения ощущений равны $\mathrm{g}=\mathrm{k}\left(\log \mathrm{b} / \mathrm{b}_{0}\right)$, где $\mathrm{g}$ - величина ощущения, $\mathrm{b}-$ величина раздражителя, $\mathrm{b}_{0}$ - пороговое значение раздражителя. Шкала ощущений не имеет абсолютного нуля, но существует значение, которому соответствует начало и окончание ощущения раздражителя (нижний и верхний абсолютный пороги чувствительности). Для обнаружения абсолютных порогов Фехнер использовал метод границ и метод постоянных раздражителей․․

\footnotetext{
${ }^{1}$ Метод границ и метод постоянных раздражителей являются модификациями методов едва заметных различий и истинных и ложных случаев соответственно.
} 
Существует значение, при котором увеличение силы раздражения уже не приводит к различению двух отличающихся по силе раздражителей (дифференциальный порог). При этом если два стимула не различаются, то, согласно закону, получается $0=\log 1$ (по формуле g - g' = k(logb/b'), где g - g' - разность ощущений, b - величина приращенного раздражителя, b' - величина исходного раздражителя).

Проблему отрицательных значений ощущений Фехнер решал следующим образом. Он полагал положительные ощущения осознанными, а отрицательные неосознанными (подпороговыми). Для измерения дифференциального порога было предложено три метода измерения дифференциальной чувствительности: метод едва заметных различий, метод истинных и ложных случаев и метод средней ошибки.

Параллельно с Фехнером над проектами изучения психики через физиологию работали Р. Лотце и В. Вундт. Работу, изданную в 1852 г., Лотце посвящает проблемам исследования простых ощущений, чувств, движений, инстинктов и др. Ссылаясь на работу Фехнера 1851 г., он отмечает, что подтверждение логарифмической зависимости было бы прекрасно, но на самом деле мы можем измерить лишь силу раздражений, но не ощущений. И тем не менее он видит в формулах Фехнера надежду на то, что в психологии будут найдены математические законы, которые позволят найти новые явления и объяснить уже известным (Lotze, 1852).

Еще один физиологический по своему эмпирическому основанию проект психологии берет свое начало в работах В. Вундта. Уже в 1862 г. Вундт попытался найти физиологические основания для психологической теории. Он предположил, что закон Вебера-Фехнера применим для описания характера взаимосвязи не только между ощущением и раздражением, но и между ощущением и восприятием. Вундт высказал идею о том, что психофизический закон остается в силе и при описании высшей психической деятельности (Wundt, 1862).

В 1874 г. выходит первое издание «Оснований физиологической психологии» В. Вундта. В предисловии Вундт по традиции оспаривает кантовские тезисы: «Первый из этих доводов ошибочен, второй, по меньшей мере, односторонен» (Вундт, 1880, с. 6) Идея неизмеримости психических явлений неверна постольку, поскольку психика обладает не одним измерением. Однако если бы Кант был прав, то, исходя из понятия величины ${ }^{2}$, измерить психику действительно было бы невозможно. В реальности наши ощущения не только распределены во времени, но и различны по интенсивности. Следовательно, интенсивность ощущений является вторым измерением. Односторонность идеи неприменимости экспериментального метода к психическим явлениям Вундт видит в следующем. Если между психическими и физическими или психическими и психическими явлениями установить причинно-следственные связи, то далее можно судить о причинах по следствиям или, наоборот, о следствиях по причинам. В случае психофизических методов как раз судят о следствиях по причинам, т.е. об ощущениях по раздражениям.

\footnotetext{
${ }^{2}$ Вундт имеет в виду физическое определение величины как объема, протяженности предмета.
} 
Тем не менее он признает, что непосредственно измерить психические явления экспериментальным путем не представляется возможным.

Как известно, при переиздании своих произведений Вундт вносил в них многочисленные поправки. Более того, с течением времени его взгляды на психологию претерпели весьма серьезные изменения. Что касается переизданий «Оснований физиологической психологии», то в первых трех изданиях прямая связь психофизики Фехнера с психологией Гербарта и тезисами Канта явно не высказывается. Но в пятом (1902-1903) и шестом (1908-1911) изданиях появляется вставка, в которой Вундт говорит об этой связи: «Фехнер имеет заслугу в том, что первым последовал тем путем, который в известных границах фактически реализовал возможность “математической психологии": этот путь указывает на экспериментальное влияние сенсорных стимулов на сознание» (Wundt, 1908, S. 40). Но далее Вундт критикует Фехнера за то, что он пытается решать не психологические, а метафизические проблемы. И в завершение определяет историческое значение Фехнера и Гербарта: «Тем не менее неизменной останется его слава как первого, кто начал реализовывать проект “строгой психологии” [“exakten Psychologie”], которую нащупал Гербарт» (Ibid.).

За десятилетие до выхода «Оснований физиологической психологии» Дробиш опубликовал статью, в которой рассматриваются ранние произведения Вундта (Drobisch, 1864). Он упрекает автора в поверхностном знании математической психологии Гербарта и психофизики Фехнера. Вундт критикует Гербарта за метафизические основания его подхода. В особенности он выступает против неизменности суммы существующих в сознании представлений, в то время как на самом деле Гербарт имел в виду то, что сумма осознанных представлений стремится оставаться стабильной. Далее, если Вундт считает неуместным говорить о «статике» и «механике» духа, которые автор использовал в метафорическом смысле, то по той же причине не стоит использовать и гербартовское понятие «порог сознания», позаимствованное Фехнером. Также возмущает Дробиша широкая трактовка закона ВебераФехнера. Он говорит о логическом, но не математическом выводе о возможности расширения закона в зону восприятия. В общем он пытается убедить читателей в том, что вундтовская попытка реформирования психологии «радикальная» и «незрелая».

Психология Гербарта, как позднее и психофизика Фехнера, вызывала критические возражения не только у его последователей и Вундта. В лучшем случае ее упрекали, например, как Лотце в «Метафизике» (Lotze, 1841), в механистическом характере, но при этом выражали надежду на то, что предложенная исследовательская программа в будущем приведет к прогрессу психологии (Ibid.).

Наиболее радикальные высказывания в адрес математической психологии принадлежат представителям неокантианства. Один из лидеров этого движения Ф.А. Ланге неоднократно выступал с критическими замечаниями в адрес математической психологии, вплоть до ее полного отрицания: «Математическая психология для нас не существует, а только мы могли бы найти в ней 
основание вникнуть еще раз точнее в метафизическую основу психологии по Канту» (Ланге, 1883, с. 331).

В 1865 г., во время работы над «Историей материализма», Ланге публикует критическое произведение о психологии Гербарта и Дробиша в ответ на рассмотренную выше статью Дробиша о психологии как естественной науке. Он говорит о том, что математическая психология пользуется хорошей репутацией в широких кругах, несмотря на фундаментальную ошибку учения Гербарта, которую унаследовали и труды Дробиша. Суть претензий сводилась к критике гербартовского подхода к выявлению суммы простых душевных сущностей, совокупность которых можно подвергнуть математическим подсчетам. Если душа является абсолютно простым образованием, то она не может видоизменяться, так как изменение можно представить только через смену порядка частей. Из математической психологии следует исключить спекулятивное утверждение о торможении суммы идей и связанные с нею пороговые формулы (Lange, 1865).

Через год выходит фундаментальный труд Ланге «История материализма и критика его нынешнего значения», в котором он резко отзывается о математической психологии в разделе «Естественнонаучная психология»: «И ведь существует целый ряд разумных и почтенных людей, которые серьезно полагают, что Гербарт своими дифференциальными уравнениями так основательно объяснил мир представлений, как Коперник и Кеплер - мир небесных тел. Это, конечно, такое же жестокое самообольщение, как френология; а что касается психологии как естественной науки, то этим прекрасным названием до такой степени злоупотребляли, что легко можно подвергнуться опасности выбросить ребенка вместе с водой из ванны» (Ланге, 1883, с. 329).

Однако в целом Ланге, как ни странно, проявляет оптимизм, говоря, что естественнонаучная психология в Германии существует, хоть и в зачаточном состоянии, еще не освободившаяся от метафизики, и в ее основе лежит именно школа Гербарта. К психофизике он оказывается более благосклонен: «Но ценность исследований Фехнера для математической психологии, конечно, не настолько низка, чтобы можно было предпочесть им даже полностью гипотетическую теорию» (Lange, 1865, S. 28). Любопытно, что при этом он считает веберовскую формулу психофизики Фехнера эмпирическим свидетельством против математической психологии!

Позднее в «Истории материализма» он высказывается более сдержанно: «Между скудными зачатками будущей научной психологии есть положение, которое учит, что - в обыкновенных пределах - ощущение возрастает как логарифм соответствующего раздражения: формула $\mathrm{x}=\log (\mathrm{y})$, которую Фехнер положил как “закон Вебера” в основание своей психофизики. Но невероятно, что этот закон имеет основание в самом сознании, а не в тех психофизических процессах, которые совершаются между внешним (физическим) раздражением и актом начала сознания» (Ланге, 1883, с. 41). В примечании Ланге добавляет, что новейшие исследования свидетельствуют в пользу того, что логарифмическая зависимость объясняется спецификой физиологии нервных окончаний. 
Действительно, психофизика Фехнера подверглась большой критике почти сразу же после выхода «Элементов психофизики» (Рибо, 1895). Вопервых, выяснилось, что закон Вебера-Фехнера верен только в известных пределах, при очень слабой и очень сильной стимуляции логарифмическая зависимость нарушается. Во-вторых, предпринимались попытки найти другую формулу, более точно описывающую связь между раздражениями и ощущениями (Stevens, 1957). В-третьих, ставился вопрос о свойствах шкалы, в которой измерялись ощущения: действительно ли это шкала равных интервалов? Отдельного внимания были удостоены «отрицательные ощущения» и корректность математического преобразования формулы Вебера в формулу Фехнера. Как показал Г. Эббингауз, Фехнер действительно допускает неоправданное допущение (Эббингауз, 1912, с. 91-94).

Особый интерес для нашей темы представляет то, как в психофизической полемике был решен вопрос об измерительных шкалах. Сам Фехнер указывал на то, что проблемы со шкалой равных интервалов нет, поскольку в ней измерялись не сами ощущения, а разности между ощущениями, которые равны между собою. Собственно, если бы формула Фехнера не имела ограничений в применении к результатам экспериментов, то можно было бы согласиться с тем, что разности ощущений действительно измеряются в шкале равных интервалов. Однако, как показал, например, Гельмгольц, это не соответствует действительности (Helmholtz, 1867).

После сомнительного успеха психофизики, спустя полвека наконец была сделана первая попытка экспериментально проверить идею Гербарта о связях идей (Boudewijnse, Murray, 2001). Г. Эббингауз в своих экспериментальных исследованиях памяти использовал для этого разработанную им методику бессмысленных слогов. При описании дизайна одного из экспериментов на воспроизведение серий бессмысленных слогов он прямо указывает на то, что идея заимствована у Гербарта. Более того, он даже цитирует пассаж из его работы, призванный проиллюстрировать теоретическую интуицию математического психолога (Ebbinghaus, 1913). В эксперименте Эббингауз оценивал последовательное воспроизведение всех стимулов, которые предъявлялись для заучивания в определенной последовательности. Силу связи элементов стимульного ряда он предложил оценивать по времени, которое проходит меду воспроизведением двух слогов, и по количеству слогов, которые вставляет испытуемый между ними (если это происходит). Вторая переменная, как бы мы сейчас сказали, отражала степень удаленности слогов друг от друга в семантическом пространстве. Тем самым Эббингауз смог измерить временны́е и пространственные характеристики психического явления (памяти). Полученные данные свидетельствовали в пользу истинности идеи Гербарта. В попытке объяснить, почему одни идеи удерживаются на уровне сознания, а другие вытесняются, он обратился за помощью к дифференциальным уравнениям.

По поводу Фехнера и психофизики Эббингауз настроен весьма скептически. Он полагает, что главная заслуга Фехнера состоит в том, что он систематизировал методы психофизики, т.е. он видел в нем в первую очередь методолога. Что касается логарифмической зависимости между раздражениями и 
ощущениями, то, рассмотрев основные критические замечания по этому поводу, Эббингауз завершает свое повествование следующим пассажем: «Отрицательные же ощущения Фехнера представляют и будут представлять для психологии только один интерес: они показывают, какие заблуждения, противные простому здравому смыслу, возможны даже у выдающихся мыслителей, когда они вызваны значительным поводом, вроде, например, красоты цельной на вид системы, или когда они прикрыты авторитетом крупного имени» (Эббингауз, 1912, с. 94).

Мы не затронули такого важного психологического применения прикладной математики, как моральная статистика ${ }^{3}$ и социальная физика А. Кетле (Кетле, 1866, 1911). Также мы не рассмотрели реакцию на нее немецких философов. Эти вопросы освещаются в ряде трудов (Дробиш, 1867; Ланге, 1883; Лотце, 1867; Wundt, 1862). Для нас сейчас важен лишь тот факт, что моральная статистика не воспринималась в Германии как бельгийская разновидность математической психологии.

Не обсуждается здесь эмпириокритицизм Р. Авенариуса, хотя по своей сути «Критика чистого опыта» является прямым следствием математической психологии Гербарта, сам он на это прямых указаний не дает (Авенариус, 1907-1908) Не случайно Вундт, давая оценку математической стороне его работы, заявил о спекулятивном характере попытки Авенариуса применить «анализ функций» к описанию человеческой психики (Вундт, 1910). Прямого влияния на дальнейшее развитие применения математики в психологии «Критика чистого опыта» не оказала. Впрочем, эмпириокритицизм способствовал переопределению предмета психологии (Авенариус, 2003; Кюльпе, 2007).

Выше мы рассмотрели основные вехи развития математической психологии и реакцию научной общественности на попытки применить математику к психологическим явлениям. Можно видеть, что с течением времени математическая психология превратилась из спекулятивной науки, тесно связанной с метафизикой, в самостоятельную научную дисциплину на границе психологии и физиологии (Липпс, 2012). В целом к началу XX в. сформировалась традиция понимать психофизику как часть математической психологии. С одной стороны, она восходила к ранним работам Фехнера, поддержанным Ланге и Вундтом (в его последних изданиях «Оснований физиологической психологии»), с другой стороны, восприятию этой науки как части экспериментальной

\footnotetext{
${ }^{3} \mathrm{C}$ темой моральной статистики тесно связаны дискуссии о свободе воли. Статистика преступности и самоубийств, выраженная в терминах вероятности, исходит из идеи эмпирической обусловленности и причинности человеческих действий. Следовательно, о свободе воли речь идти не может. Впрочем, психофизический закон противоречит положению о человеческом волеизъявлении. Суть сводится к тому, что если мы полагаем причинно-следственную связь между физическим миром и психическими реакциями, то эти реакции оказываются неизбежными. Обширные дискуссии на тему свободы воли не имеют прямого отношения к теме нашего исследования, хотя и касаются оппозиции метафизики и психологии, поэтому здесь мы считаем достаточным дать лишь краткую справку об этой философской проблеме.
} 
психологии, идущему от Вундта. Такая двойственность связей психофизики обусловила специфическую роль математической психологии в дисциплинарном конфликте конца XIX - начала XX в., так как позволила приравнять математическую психологию к экспериментальной. Смешение математической психологии с экспериментальной психологией довершил Эббингауз в экспериментальных исследованиях памяти.

\section{Дисциплинарный конфликт и границы допустимого}

Возможность пересмотра традиционных дисциплинарных границ психологии обсуждалась начиная с момента появления математической психологии. С самого начала этот процесс сопровождался попытками отнести психологию к «объяснительным» и/или «описательным» наукам. В результате к концу XIX в. дискуссии о месте психологии в классификации наук и ее независимости от философии будут вестись с использованием именно этой терминологии. Соответственно, наша задача состоит в анализе вариантов, способов определения и защиты ее дисциплинарных границ.

Уже в 1842 г. Дробиш в «Эмпирической психологии, согласно научному методу» поставил вопрос о возможности классифицировать психологию как естественную науку и вывести ее из числа философских наук. Психология, с его точки зрения, руководствуется тремя методами исследования: описательным, классифицирующим и объяснительным. По мнению Дробиша, под объяснительной психологией традиционно понимают психологию, образцом для которой послужила физическая наука (Drobisch, 1842).

Внутренняя методологическая расщепленность академической психологии усугубилась с началом применения экспериментального метода к исследованию психических явлений. В одной из своих ранних работ Вундт писал, что психологии необходимо перестать находиться под влиянием метафизики и начать формулировать собственные законы (Wundt, 1862).

Глава баденской школы неокантианства В. Виндельбандт в 1876 г. по случаю вступления в должность профессора философии в Цюрихе выступил с речью о связи философии с эмпирическими науками, в первую очередь с психологией. Он говорил о том, что, с одной стороны, все привыкли, что психология входит в состав философских дисциплин, но, с другой стороны, она все дальше удаляется от своих метафизических основ и все больше обращается к эмпирическим методам исследования. Виндельбандт считал, что недалеко то время, когда психология полностью потеряет связь с метафизикой и превратится, как считал Ланге, в «психологию без души». «Обоснование и закрепление эмпирического метода в психологии поэтому самым тесным образом связано с ее освобождением от оков метафизики» (Windelband, 1876, S. 6). Развитие эмпирической психологии он ставил в заслугу «разрушительной критике

\footnotetext{
${ }^{4}$ «Если иметь в виду главным образом самостоятельность метода, то нашу науку (физиологическую психологию.) - C.M. можно назвать экспериментальной психологией, в отличие от психологии, основанной исключительно на самонаблюдении» (Вундт, 1880, с. 2).
} 
Гербарта». Далее Виндельбандт делал вывод о возможности открытия самостоятельных кафедр психологии. В завершение он отмечал, что для успешного применения математики в этой науке необходимо выработать свою четкую систему понятий.

В это же время в немецкой философии был популярен психологизм. Его основная идея была противоположна сепаратистским настроениям, она сводилась к попыткам создать проект философии на фундаменте психологии. К представителям этого течения можно отнести В. Дильтея с его описательной психологией и др. Основная проблема психологистических проектов состояла в том, чтобы четко определить, какой должна быть психология, на фундаменте которой можно основать знание наук о духе.

Острые дискуссии об описательной и объяснительной психологии, возможно, никогда бы и не возникли, так как оба направления методологически слишком далеки друг от друга, если бы не Дильтей. Он попытался не просто предложить свой вариант описательной психологии, но и заменить им естественно-научное направление психологии. В 1894 г. Дильтей опубликовал «Идеи к описательной и расчленяющей психологии», которые вызвали острую критику со стороны Эббингауза. Его труд посвящен критическому анализу объяснительной и описательной психологии. К объяснительной психологии он отнес математическую психологию, психофизику, экспериментальную психологию. Ярчайшим ее представителем, на которого была обрушена вся дильтеевская критика, является Гербарт. Анализ математической психологии привел автора к мысли, что в психологии невозможно формулировать гипотезы и затем проверять их истинность. Однако развитие психофизических методов в экспериментальной психологии вызвало популярность естественно-научной методологии в науке о психических явлениях. Но господство объяснительной психологии, в частности психофизики, вредно для развития наук о духе. Альтернативой такой психологии может стать описательная психология, которая составила бы ей прочную опору в теории и системе психологических понятий (Дильтей, 1996).

Оппонентом Дильтея стал Эббингауз, который показал, что математическая психология и современная ему экспериментальная психология - это две разные дисциплины. Он обвинил Дильтея в том, что тот не знает современного состояния психологии и опирается в своей критике на работы полувековой давности. Большинство упреков, которые предъявлены объяснительной психологии, на самом деле относятся только к учению Гербарта. Эббингауз особенно подчеркивал независимость современной эмпирической психологии от него: «Гербарт, конечно, приобрел значение в пределах Германии. Но его метафизическая изощренность, его необоснованные фикции, его мифологемы всегда служили ему преградой для выхода за ее пределы. <...> Более того, если обозреть живую психологическую исследовательскую работу современности во всей широте и объеме, то обнаружится, что она ни от кого не была дальше умственно отделена так, как именно от Гербарта» (Эббингауз, 2014, с. 164). Мало того, Дильтей также не ориентировался в работах современной «описательной психологии». В целом его работа отличалась бессодержательностью, 
а размышления о неприменимости гипотез к психическим явлениям, которые использовались как главный аргумент против объяснительной психологии, необоснованностью. Критика Эббингауза оказалась настолько жесткой, что Дильтей так и не смог ответить на нее (Куренной, 2014).

Мы можем видеть, что в поздней критике математической психологии изменились акценты. Дильтей обращал внимание не только на механистичность гербартовского подхода, но в первую очередь на способ построения знания через выдвижение научных гипотез. Напротив, Эббингауз указывал на важность гипотез в научном знании. Он говорил о том, что психологическая теория содержит в себе не абсолютные истины, ее положения могут быть эмпирически опровергнуты. Особенно возможности верификации возросли после «глубокой по своим последствиям революции» - введения в методологию психологии экспериментального метода. В этом отношении психология не отличается от других естественных и точных наук. Здесь важно подчеркнуть, что Дильтей не выступал категорически против экспериментов в психологии (Ash, 1980b).

Дильтей и позднее другие представители немецкой философии рубежа веков все более отчетливо осознавали тот факт, что современная им психология со всеми ее экспериментами и измерениями не может оказаться полезной при разработке методологии гуманитарных дисциплин, которые представляли для них основной интерес. Так, Риккерт в «Науках о природе и науках о культуре» приветствовал психологические идеи Дильтея (Риккерт, 1998). В итоге это привело представителей неокантианства к идее, что «объяснительная психология» должна быть независима от философии, причем дисциплинарно. П. Наторп, инициатор открытого движения за академическое оформление разделения психологии и философии, писал: «Поручить философу университетское преподавание психологии или психологу - философии имело бы не больше оснований, нежели поручить философу преподавать также математику, или биологию, или...» (Наторп, 2006, с. 39).

Определенную роль в радикальных настроениях академических философов на рубеже веков сыграла идея о кризисе немецкой науки. Тема кризиса достаточно хорошо раскрыта Ф. Рингером в «Закате немецких мандаринов» (Рингер, 2008). Первым о методологическом кризисе заговорили Р. Авенариус и Э. Мах, причем кризисе не только психологии, но и науки в целом (Авенариус, 1907-1908; Mülberger, 2012). В истории математической психологии дискуссии о методологическом кризисе играют второстепенную роль, поэтому подробно останавливаться на них мы не будем. В целом общие кризисные настроения в среде психологов и философов все более и более усиливались начиная с конца 1890-х гг.

С нашей точки зрения, кризис в немецкой психологии в первую очередь был вызван особенностями академической политики и государственного финансирования научных исследований. Как известно, с открытием экспериментальной лаборатории в Лейпциге в 1879 г. началась новая эра научной психологии. В конце XIX в. в Германии насчитывалось уже четыре психологические лаборатории (института): вундтовская в Лейпциге, а также в 
Берлине, Вюрцбурге и Геттингене. Однако институциализация экспериментальной психологии проходила медленно. Официальное признание от университета Психологический институт Вундта получил в 1883 г., но регулярные государственные субсидии на него стали выделяться только с середины 1890-х гг. Не менее драматично обстояли дела с Берлинским институтом Штумпфа. Начиная с конца 1890-х гг. он неоднократно был вынужден просить германское правительство увеличить штат сотрудников института, предоставить новые помещения для лабораторий и субсидии. Об общем состоянии академических штатов и лабораторий можно судить по данным, которые приводит М. Аш (Ash, 1980a, p. 273).

Скромное финансирование академической психологии не смогло остановить процесс роста количества психологов в академической среде. Возникало все больше социальных институций, утверждающих дисциплинарный статус психологии. В конце века появились немецкоязычные специализированные журналы по психологии, психологические общества, стали проводиться конференции. В 1890 г. Эббингауз и А. Кениг начали издавать «Журнал по психологии и физиологии органов чувств». С 1903 г. Э. Мойман издавал «Архив общей психологии». В 1904 г. было основано Общество экспериментальной психологии.

На открытии V съезда Общества экспериментальной психологии в 1912 г. часть участников прямо выступали за создание психологических кафедр и профессорских должностей по психологии (Ash, 1980a). Через два года на VI съезде Общества экспериментальной психологии Мюллер жаловался на отсутствие финансирования экспериментальной психологии и трудности в работе Психологического института в Геттингене (Ash, 1980b).

Здесь стоит уточнить, что на самом деле количество психологов с академической аккредитацией значительно возросло: в 1892 г. психологи занимали три ординарные профессорские кафедры, а в 1910 г. уже десять (Куш, 2002). Но конкуренция за профессорские ставки все равно оставалась слишком жесткой. Что касается финансирования, то оно в разы уступало материальной поддержке в Германии, например, физических наук (Ash, 1980b).

В 1912 г. Кюльпе опубликовал статью «Психология и медицина». В ней он предлагал в каждом немецком университете открыть психологические институты, а также ввести психологию в качестве обязательного предмета для медиков, в связи с этим открыть кафедры психологии на медицинских факультетах. Обоснование своей позиции он видел в том, что молодые психологи нередко специализируются именно в психологии, поверхностно осваивая философские дисциплины (Külpe, 1912). Но после выхода в свет статья не имела общественного резонанса, поэтому в 1914 г. Кюльпе внес новое предложение о выделении психологии в качестве самостоятельной научной дисциплины в рамках философского факультета (Ash, 1980b).

Вскоре ситуация вышла за пределы академического мира. В 1912 г. Наторп выступил в ведущей франкфуртской газете с заявлением, в котором опротестовал получение экспериментальным психологом Э. Йеншем вместо неокантианца Когена профессорского звания на философском факультете 
Марбургского университета. В начале 1913 г. Гуссерль, Наторп, Риккерт и другие ученые составили заявление, адресованное всем немецкоязычным университетам и министерствам образования: «Экспериментальная психология, следовательно, должна быть поддержана только через введение должностей профессоров психологии, и везде, где предварительно должности профессоров философии заняты [психологами], должны быть учреждены новые кафедры философии» (Kusch, 1995, р. 188). Анализ заявления позволяет сделать вывод о том, что авторы явно позаимствовали аргументы из рассмотренной выше речи Виндельбандта и статьи о психологии и медицине Кюльпе, усилив свою аргументацию ссылкой на «кризисное» состояние немецкой философии и повышение интереса студентов к философии жизни, одним из основателей которой считается Дильтей. Особенно важно для нас то, что нападкам подверглись именно экспериментальные психологи, а не представители «объяснительной психологии» и тем более математической психологии. После полемики Эббингауза с Дильтеем математическая психология оказалась дисциплиной прошлого, потерявшей свою актуальность.

Заявление имело большой резонанс в печати. Его подписали 107 философов из Германии, Австрии и Швейцарии. Со стороны психологов оно вызвало резко негативную реакцию, так как выходило за рамки академической полемики. Однако по поводу дисциплинарной независимости существовали разные мнения. Так, Вундт в статье «Психология в борьбе за существование» выступил против исключения психологии из состава философии. Он считал, что потеря психологией философских корней равносильна смерти дисциплины (Вундт, 1913).

C началом Первой мировой войны дисциплинарная борьба за независимость немецкой психологии фактически закончилась. Кроме военного положения, причиной тому послужило смещение акцента с неокантианства в сторону феноменологии Э. Гуссерля. Попытки обороняться от «нападения» психологии на философию прекратились (Куш, 2004). Гуссерль объявил полемическое эссе Дильтея первой атакой на «натуралистическую психологию», гениальной по своей интуиции. Конечно, экспериментальная психология поначалу смогла отбиться, но ее главный недостаток - неспособность объяснить факты духовной жизни, а следовательно, и оказаться полезной для наук о духе (Гуссерль, 2014).

Еще Гербарт в 1822 г. предупреждал: «Математика - господствующая наука нашего времени. Ее завоевания возрастают ежедневно, хотя и без шума. Кто не имеет ее за себя, тот некогда будет иметь ее против себя» (Гербарт, 2007a, с. 53). История математической психологии показала, что даже в том случае, когда речь шла лишь о математике как о методе, в философских дисциплинах разворачивались настоящие баталии, в которых представители разных методологических лагерей пытались отстоять свою независимость. 


\section{Литература}

Авенариус, Р. (1907-1908). Критика чистого опыта. СПб.: И.В. Шестаковский и И.П. Федоров. Авенариус, Р. (2003). О предмете психологии. М.: Едиториал УРСС.

Андреев, А. Ю. (2009). Российские университеты XVIII - первой половины XIX века в контексте университетской истории Европы. М.: Знак.

Бен-Дэвид, Д. (2014). Роль ученого в обществе. М.: Новое литературное обозрение.

Бен-Дэвид, Д., Коллинз, Р. (2002). Социальные факторы при возникновении новой науки: случай психологии. Логос, 35(5-6), 1-30.

Вундт, В. (1880). Основания физиологической психологии. М.: Н.А. Абрикосов.

Вундт, В. (1910). О наивном и критическом реализме. Имманентная философия и эмпириокритицизм. М.: Издание М. и С. Сабашниковых.

Вундт, В. (1913). Психология в борьбе за существование. В кн. Новые идеи в философии: Сб. 10. Методы психологии (с. 91-131). СПб.: Изд-во «Образование».

Гербарт, И. Ф. (2007, а). О возможности и необходимости применять в психологии математику. В кн. И. Ф. Гербарт, Психология (с. 39-56). М.: Издательский дом «Территория будущего».

Гербарт, И. Ф. (2007, б). Психология как наука, вновь обоснованная на опыте, метафизике и математике. В кн. И. Ф. Гербарт, Психология (с. 58-116). М.: Издательский дом «Территория будущего».

Гуссерль, Э. (2014). Введение к лекциям по феноменологической психологии (1925). Логос, 100(4), 187-214.

Демин, М. (2013). Немецкий университет XIX века и дисциплинарная специализация философии. Логос, 91(1), 240-261.

Дильтей, В. (1996). Описательная психология (2-е изд.). СПб.: Алетейя/Кренов.

Дмитриев, А. Н., Савельева, И. М. (ред.). (2015). Науки о человеке: история дисииплин. М.: ИД Высшей школы экономики.

Дробиш, М. (1867). Нравственная статистика. СПб.: Издание Н.И. Ламанского.

Кант, И. (1994). Метафизические начала естествознания. В кн. И. Кант, Сочинения (т. 4, с. $247-$ 372). М.: ЧОРО.

Кетле, Л. А. Ж. (1866). Социальная система и законы, ею управляющие. СПб.: Н. Поляков и К․

Кетле, Л. А. Ж. (1911). Социальная физика, или Опьт исследования о развитии человеческих способностей (т. 1). Киев: Типография И.И. Чоколова.

Куренной, В. (2005). К вопросу о возникновении феноменологического движения. Логос, 5(50), $247-275$.

Куренной, В. (2014). Полемика профессионалов: конкуренция и опровержение исследовательских программ в современной философии. Логос, 100(4), 105-146.

Куш, М. (2002). Социология философского знания: конкретное исследование и защита. Логос, $5-6(35), 1-31$.

Куш, М. (2004). Победителю достается все: Философия жизни и триумф феноменологии. Логос, 3(43), 167-200.

Кюльпе, О. (2007). Введение в философию. М.: Изд-во ЛКИ.

Ланге, Ф. А. (1883). История материализма и критика его значения в настоящее время: T. 2. История материализма после Канта. СПб.: Издание Л.Ф. Пантелеева.

Липпс, Г. Ф. (2012). Основы психофизики. М.: КомКнига.

Лотце, Р. Г. (1867). Микрокозм: Мысли о естественной и бытовой истории человечества: Опыт антропологии (ч. 3). М.: Издание К. Солдатенкова. 
Наторп, П. (2006). Философия и психология. В кн. П. Наторп, Избранные работы (с. 25-54). М.: Издательский дом «Территория будущего».

Поппер, К. Р. (1992). Открытое общество и его враги: Т. 2. Время лжепророков: Гегель, Маркс и другие оракулы. М.: Феникс/Международный фонд «Культурная инициатива».

Рибо, Т. (1895). Современная германская психология. Опьтная школа. СПб.: Паровая скоропечатня А. Пороховщикова.

Риккерт, Г. (1998). Науки о природе и науки о культуре. В кн. Г. Риккерт, Науки о природе и науки о культуре (с. 43-128). М.: Республика.

Рингер, Ф. (2008). Закат немеиких мандаринов: Академическое сообщество в Германии, 18901933. М.: Новое литературное обозрение.

Сокулер, 3. А. (2001). Знание и власть: наука в обществе модерна. СПб.: РХГИ.

Суходоев, В. В. (б.д.). Модифицированная методика измерений и оценки кожно-гальванических реакций человека. Режим доступа: http://www.ipras.ru/cntnt/rus/media/on-laynbibliote/otdelnie-stati-s/publikacii/stati_sotr/vvsuhodeev.html

Шнедельбах, Г. (2002). Университет Гумбольдта. Логос, 5-6(35), 1-14.

Эббингауз, Г. (1912). Основы психологии (т. 1, вып. 2). СПб.: Издание товарищества «Общественная Польза».

Эббингауз, Г. (2014). Об объясняющей и описательной психологии. Логос, 100(4), 147-186.

Юдин, Г. (2015). Наукоучение Эдмунда Гуссерля и кризис теории разделения наук. В кн. А. Н. Дмитриев, И. М. Савельева (ред.), Науки о человеке: история дисциплин (с. 240-262). М.: ИД Высшей школы экономики.

Ссылки на зарубежные источники см. в разделе References после англоязычного блока.

Морозова Светлана Васильевна - старший преподаватель, кафедра общей психологии, факультет психологии, Санкт-Петербургский государственный университет, кандидат психологических наук.

Сфера интересов: количественная психология, история психологии, экспериментальная психология.

Контакты: svmpsy@gmail.com

\title{
Mathematische Psychologie: History of Conflict
}

\author{
S.V. Morozova ${ }^{a}$ \\ ${ }^{a}$ Saint Petersburg State University, 6 Makarova emb., Saint Petersburg, 199034, Russian Federation
}

\begin{abstract}
The article describes the role of the mathematische Psychologie in the German philosophical discourse of the 19th - early 20th centuries. The history of mathematical psychology is viewed from the standpoint of the disciplinary approach in historiography. The author focuses on the reconstruction of social mechanisms that determine the content of the discipline, its relationship
\end{abstract}


with the structure and specifics of the functioning of universities and academic institutions, as well as academic corporations. The author shows that several times mathematical psychology had been in the center of disciplinary conflicts. At first, it was a subject of controversy between the Herbartarians and the Neo-Kantians. After the publication of Fechner's Elements of Psychophysics, academic philosophers perceived physiological psychology as "mathematical psychology". By the end of the 19th century, after the heyday of psychophysics, during the rise of a new wave of Neo-Kantianism, the psychology of Herbart and psychophysics became the subject of a polemic between Dilthey and Ebbinghaus about the revision of the methodological bases of psychology. The discussion of the early 20th century on the exclusion of experimental psychology from the list of philosophical disciplines completes the process of turning to mathematical psychology as an argument for defining the disciplinary boundaries. The history of mathematische Psychologie showed that even when it was only a question of mathematics as a method, real battles took place in philosophical disciplines, in which representatives of different methodological camps tried to defend their independence. Started as a philosophical argument, the debate on the mathematische Psychologie gradually turned into a branding of the methodologically backward and outdated.

Keywords: mathematische Psychologie, mathematical psychology, history of psychology, disciplinary conflict, academic policy.

\section{References}

Andreev, A. Yu. (2009). Rossiiskie universitety XVIII - pervoi poloviny XIX veka v kontekste universitetskoi istorii Evropy [Russian universities of the $18^{\text {th }}-$ early $19^{\text {th }}$ century in the context of university history of Europe]. Moscow: Znak. (in Russian)

Ash, M. G. (1980, a). Academic politics in the history of science: experimental psychology in Germany, 1879-1941. Central European History, 13(3), 255-286.

Ash, M. G. (1980, b). Experimental psychology in Germany before 1914: aspects of an academic identity problem. Psychological Research, 42, 75-86.

Avenarius, R. (1907-1908). Kritika chistogo opyta [Critique of pure experience]. Saint Petersburg: I.V. Shestakovskii i I.P. Fedorov. (in Russian)

Avenarius, R. (2003). O predmete psikhologii [On the subject of psychology]. Moscow: Editorial URSS. (in Russian)

Backhouse, R. E., \& Fontaine, P. (Eds.). (2010). The history of social sciences since 1945. Cambridge: Cambridge University Press.

Ben-David, J. (2014). Rol' uchenogo v obshchestve [The scientist's role in society]. Moscow: Novoe literaturnoe obozrenie. (in Russian; trans. of: Ben-David, J. (1971). The scientist's role in society. A comparative study. Englewood Cliffs, NJ/London: Prentice-Hall.)

Ben-David, J., \& Collins, R. (2002). Sotsial'nye faktory pri vozniknovenii novoi nauki: sluchai psikhologii [Social factors in the origins of a new science: The case of psychology]. Logos, 35(5-6), 1-30. (in Russian; trans. of: Ben-David, J., \& Collins, R. (1966). Social factors in the origins of a new science: The case of psychology. American Sociological Review, 31(4), 451-465.)

Boudewijnse, G.-J. A., \& Murray, D. J. (2001). The fate of Herbart's mathematical psychology. History of Psychology, 4(2), 107-132. 
Danziger, K. (1998). Constructing the Subject: historical origins of psychological research. Feminisms Redux. Cambridge: Cambridge University Press.

Demin, M. (2013). Nemetskii universitet XIX veka i distsiplinarnaya spetsializatsiya filosofii [German university of the $19^{\text {th }}$ century and disciplinary specialization of philosophy]. Logos, 91(1), 240-261. (in Russian)

Dilthey, W. (1996). Opisatel'naya psikhologiya [Descriptive psychology] (2nd ed.). Saint Petersburg: Aleteiya/Krenov. (in Russian)

Dmitriev, A. N., \& Savelieva, I. M. (Eds.). (2015). Nauki o cheloveke: istoriya distsiplin [Sciences of man: History of the disciplines]. Moscow: HSE Publishing House. (in Russian)

Drobisch, M. W. (1842). Empirische Psychologie nach naturwissenschaftlicher Methode [Empirical psychology on the natural scientific method]. Leipzig. (in German)

Drobisch, M. W. (1850). Erste Grundlehren der mathematischen Psychologie. Mit einer Figurentafel [The first basic teachings of the mathematical psychology. With the figure panel]. Leipzig. (in German)

Drobisch, M. W. (1864). Ueber den neuesten Versuch die Psychologie naturwissenschaftlich zu begründen [On the latest attempt to explain psychology in scientific terms]. Zeitschrift für exacte Philosophie, 4, 313-348. (in German)

Drobisch, M. (1867). Nravstvennaya statistika [Moral statistics]. Saint Petersburg: Izdanie N.I. Lamanskogo. (in Russian)

Ebbinghaus, H. (1912). Osnovy psikhologii [Principles of psychology] (Vol. 1, iss. 2). Saint Petersburg: Izdanie tovarishchestva "Obshchestvennaya Pol'za". (in Russian)

Ebbinghaus, H. (1913). Memory: a contribution to experimental psychology. New York, NY: Teachers College, Columbia University.

Ebbinghaus, H. (2014). Ob ob»yasnyayushchei i opisatel'noi psikhologii [On the explanatory and descriptive psychology]. Logos, 100(4), 147-186.

Fechner, G. T. (1860). Elemente der Psychophysik [Elements of psychophysics] (Erster Theil). Leipzig: Breitkopf und Hдrtel. (in German)

Fechner, G. T. (1987). Outline of a new principle of mathematical psychology (1851). Psychological Research, 49(4), 203-207. doi:10.1007/BF00309027

Hatfield, G. (2003). Psychology: old and new. In T. Baldwin (Ed.), The Cambrige history of philosophy: 1870-1945 (pp. 93-106). Cambridge: Cambridge University Press.

Helmholtz, H., von. (1867). Handbuch der physiologischen Optik [The manual on the physiological Optics]. Leipzig: Leopold Voss. (in German)

Herbart, J. F. (2007, a). O vozmozhnosti i neobkhodimosti primenyat' v psikhologii matematiku [On the possibility and necessity to apply mathematics in psychology]. In J. F. Herbart, Psikhologiya [Psychology] (pp. 39-56). Moscow: Izdatel'skii dom "Territoriya budushchego". (in Russian)

Herbart, J. F. (2007, b). Psikhologiya kak nauka, vnov' obosnovannaya na opyte, metafizike i matematike [Psychology as a science, which is based on experience, metaphysics and mathematics]. In J. F. Herbart, Psikhologiya [Psychology] (pp. 58-116). Moscow: Izdatel'skii dom "Territoriya budushchego". (in Russian)

Husserl, E. (2014). Vvedenie k lektsiyam po fenomenologicheskoi psikhologii [Introduction to the lectures on phenomenological psychology] (1925). Logos, 100(4), 187-214. (in Russian)

Kant, I. (1994). Metafizicheskie nachala estestvoznaniya [Metaphysical foundations of natural science]. In I. Kant, Sochineniya [Writings] (Vol. 4, pp. 247-372). Moscow: ChORO. (in Russian)

Külpe, O. (1912). Psychologie und medizing [Psychology and medicine]. Zeitschrift für Pathopsychologie, 1, 187-267. (in German)

Külpe, O. (2007). Vvedenie v filosofiyu [Introduction to philosophy]. Moscow: Izdatel'stvo LKI. (in Russian) 
Kurennoy, V. (2005). K voprosu o vozniknovenii fenomenologicheskogo dvizheniya [On the issue of the rise of phenomenological movement]. Logos, 5(50), 247-275. (in Russian)

Kurennoy, V. (2014). Polemika professionalov: konkurentsiya i oproverzhenie issledovatel'skikh programm $\mathrm{v}$ sovremennoi filosofii [Polemics of the professionals: competition and refutation of research programs in contemporary philosophy]. Logos, 100(4), 105-146. (in Russian)

Kusch, M. (1995). Psychologism: A case study in the sociology of philosophical knowledge. London/New York, NY: Routledge.

Kusch, M. (2002). Sotsiologiya filosofskogo znaniya: konkretnoe issledovanie i zashchita [Sociology of philosophical knowledge: a case study and a defense]. Logos, 5-6(35), 1-31. (in Russian)

Kusch, M. (2004). Pobeditelyu dostaetsya vse: Filosofiya zhizni i triumf fenomenologii [The winner gets it all: Philosophy of life and the triumph of phenomenology]. Logos, 3(43), 167-200. (in Russian)

Lange, F. A. (1865). Die Grundlegung der mathematischen Psychologie. Ein Versuch zur Nachweisung des fundamentalen Fehlers bei Herbart und Drobisch [The foundation of mathematical psychology. An attempt to prove the fundamental error of Herbart and Drobisch]. Duisburg: Verlag von W. Falk \& Volmer. (in German)

Lange, F. A. (1883). Istoriya materializma i kritika ego znacheniya v nastoyashchee vremya: T. 2. Istoriya materializma posle Kanta [The history of materialism and critique of its significance today. Vol. 2. History of materialism after Kant]. Saint Petersburg: Izdanie L.F. Panteleeva. (in Russian)

Lipps, G. F. (2012). Osnovy psikhofiziki [Foundations of psychophysics]. Moscow: KomKniga. (in Russian)

Lotze, H. (1841). Metaphysik [Metaphysics]. Leipzig: Weidmann'sche buchhandlung. (in German)

Lotze, H. (1852). Medicinische Psychologie, oder Physiologie der Seele [Medical psychology, or the psychology of soul]. Leipzig: Weidmann'sche buchhandlung. (in German)

Lotze, R. H. (1867). Mikrokozm: Mysli o estestvennoi i bytovoi istorii chelovechestva: Opyt antropologii [Microcosm: Thoughts on the natural and common history of mankind: An experience in anthropology] (Pt. 3). Moscow: Izdanie K. Soldatenkova. (in Russian)

Mülberger, A. (2012). Wundt contested: The first crisis declaration in psychology. Studies in History and Philosophy of Biological and Biomedical Sciences, 43, 434-444.

Natorp, P. (2006). Filosofiya i psikhologiya [Philosopy and psychology]. In P. Natorp, Izbrannye raboty [Selected works] (pp. 25-54). Moscow: Izdatel'skii dom "Territoriya budushchego". (in Russian)

Popper, K. R. (1992). Otkrytoe obshchestvo i ego vragi: T. 2. Vremya lzheprorokov: Gegel', Marks i drugie orakuly [Open society and its enemies: Vol. 2. The time of false prophets: Hegel, Marx and other oracles]. Moscow: Feniks/Mezhdunarodnyi fond "Kul'turnaya initsiativa". (in Russian)

Quetelet, L.-A.-J. (1866). Sotsial'naya sistema i zakony, eyu upravlyayushchie [Social system and laws that govern it]. Saint Petersburg: N. Polyakov i K०. (in Russian)

Quetelet, L.-A.-J. (1911). Sotsial'naya fizika, ili Opyt issledovaniya o razvitii chelovecheskikh sposobnostei [Social physics, or the Effort of research on the development of human abilities] (Vol. 1). Kiev: Tipografiya I.I. Chokolova. (in Russian)

Ribot, T. (1895). Sovremennaya germanskaya psikhologiya. Opytnaya shkola [Modern German psychology. School of experience]. Saint Petersburg: Parovaya skoropechatnya A. Porokhovshchikova. (in Russian)

Rickert, H. (1998). Nauki o prirode i nauki o kul'ture [The natural sciences and the cultural sciences]. In H. Rickert, Nauki o prirode i nauki o kul'ture [The natural sciences and the cultural sciences] (pp. 43-128). Moscow: Respublika. (in Russian)

Ringer, F. (2008). Zakat nemetskikh mandarinov: Akademicheskoe soobshchestvo v Germanii, 18901933 [The decline of the German mandarins: the German academic community, 1890-1933]. 
Moscow: Novoe literaturnoe obozrenie. (in Russian; trans. of: Ringer, F. (2008). The decline of the German mandarins: the German academic community, 1890-1933. Cambridge: Harvard Unviversity Press.)

Schnädelbach, P. (2002). Universitet Gumbol'dta [Humboldt university]. Logos, 5-6(35), 1-14. (in Russian)

Sokuler, Z. A. (2001). Znanie i vlast': nauka v obshchestve moderna [Knowledge and power: Science in the modern society]. Saint Petersburg: RKhGI. (in Russian)

Stevens, S. S. (1957). On the psychophysical law. Psychological Review, 64(3), 153-181. doi:10.1037/h0046162

Sturm, T. (2012). Bühler and Popper: Kantian therapies for the crisis in psychology. Studies in History and Philosophy of Biological and Biomedical Sciences, 43(2), 462-72. doi:10.1016/j.shpsc.2011.11.006

Sturm, T., \& Mülberger, A. (2012). Crisis discussions in psychology - New historical and philosophical perspectives. Studies in History and Philosophy of Biological and Biomedical Sciences, 43(2), 42533. doi:10.1016/j.shpsc.2011.11.001

Sukhodoev, V. V. (s. d.). Modifitsirovannaya metodika izmerenii i otsenki kozhno-gal'vanicheskikh reaktsii cheloveka [Modified technique of measurement and assessment of galvanic skin reaction of a man]. Retrieved from http://www.ipras.ru/cntnt/rus/media/on-layn-bibliote/otdelnie-statis/publikacii/stati_sotr/vvsuhodeev.html (in Russian)

Windelband, W. (1876). Über den gegenwärtigen Stand der psychologischen Forschung: Rede zum Antritt der ordentlichen Professur der Philosophie an der Hochschule zu Zürich am 20. Mai 1876 gehalten [On the current state of psychological research: Speech at the inauguration of the full professorship of philosophy at the University of Zurich on May, 20, 1876]. Leipzig: Drück und Verlag von Breitkopf \& Härtel. (in German)

Wundt, W. (1862). Beiträge zur Theorie der Sinneswahrnehmung [Contributions to the theory of sensory perception]. Leipzig/Heidelberg: C. F. Winter'sche Verlagshandlung. (in German)

Wundt, W. (1877). Philosophy in Germany. Mind, 2(8), 493-518.

Wundt, W. (1880). Osnovaniya fiziologicheskoi psikhologii [Principles of physiological psychology]. Moscow: N.A. Abrikosov. (in Russian)

Wundt, W. (1908). Grundzüge der physiologischen Psychologie [Principles of physiological psychology] (Erster Band). Leipzig: Verlag von Wilhelm Engelmann. (in German)

Wundt, W. (1910). O naivnom i kriticheskom realizme. Immanentnaya filosofiya i empiriokrititsizm [On the naive and critical realism. The immanent philosophy and empirio-criticism]. Moscow: Izdanie M. i S. Sabashnikovykh. (in Russian)

Wundt, W. (1913). Psikhologiya v bor'be za sushchestvovanie [Psychology in the struggle for existence]. In Novye idei v filosofii: Sb. 10. Metody psikhologii [New ideas in philosophy: Digest 10. Psychological methods] (pp. 91-131). Saint Petersburg: Obrazovanie. (in Russian)

Yudin, G. (2015). Naukouchenie Edmunda Gusserlya i krizis teorii razdeleniya nauk [The science teaching by Edmund Husserl and the crisis of theory division of sciences]. In A. N. Dmitriev \& I. M. Savelieva (Eds.), Nauki o cheloveke: istoriya distsiplin [Sciences of man: History of disciplines] (pp. 240-262). Moscow: HSE Publishing House. (in Russian)

Svetlana V. Morozova - Senior Lecturer, Faculty of Psychology, Saint Petersburg State University, PhD in Psychology.

Research Area: quantitative psychology, history of psychology, experimental psychology.

E-mail: svmpsy@gmail.com 